\title{
Monitoring Suhu dan Kelembaban Tanah pada Budidaya Porang Berbasis Arduino
}

\author{
Eko Budihartono ${ }^{1}$, Arif Rakhman ${ }^{2}$, Dwie Kukuh Supriyono ${ }^{2}$ \\ Email: tara.niscita@gmail.com ${ }^{1}$, cakrakirana7@gmail.com ${ }^{3}$, dwiekukuhs@gmail.com² \\ Prodi D-3 Teknik Komputer, Politernik Harapan Bersama ${ }^{1,2,3}$
}

\begin{abstract}
Abstrak
Tanah merupakan campuran dari beberapa komponen seperti mineral, senyawa organic, senyawa anorganik dan air. Tanah menyediakan air, udara dan nutrisi yang dibutuhkan makhluk hidup seperti organisme tanah dan tumbuhan. Dalam bidang pertanian tanah diartikan lebih khusus yaitu sebagai media tumbuhnya tanaman darat seperti pada budidaya porang. Porang (Amorphophallus oncophyllus Prain) sebagai tanaman penghasil, karbohidrat, lemak, protein, mineral, vitamin, dan serat pangan, tanaman porang sudah lama dimanfaatkan sebagai bahan pangan dan diekspor. Manfaat porang dapat dimanfaatkan pada berbagai industri pangan, kimia, dan farmasi. Keberhasilan dan kegagalan dalam budidaya porang ditentukan oleh kualitas tanah dan manajemen penggunaannya. Ketersediaan air pada masa pertumbuhan harus diperhatikan, jika kekurangan air daun porang akan kering dan akhirnya mati. Dengan terpenuhinya kebutuhan air pada tanaman, maka tanaman dapat tumbuh dan berkembang biak dengan baik. Penelitian ini menerapkan alat monitoring suhu dan kelembaban tanah otomatis pada tanaman porang menggunakan sensor suhu dan kelembaban tanah berbasis Arduino agar dapat membantu meningkatkan hasil panen tanaman menjadi lebih baik. Hasil dari penelitian ini akan diuji coba untuk menilai seberapa baik alat yang telah dibuat. Parameter yang dimonitoring adalah suhu dan kelembaban tanah yang akan terbaca pada LCD yang dipasang pada tanah di sekitar tanaman porang secara otomatis. Alat monitoring suhu dan kelembaban pada budidaya porang dapat mempermudah proses pengukuran suhu dan kelembaban tanah bekerja secara otomatis dengan keakuratan 99\% dan alat ini hanya membutuhkan catu daya.
\end{abstract}

Kata kunci : Arduino Uno, Sensor Suhu, Sensor Kelembaban Tanah, LCD

\section{Pendahuluan}

Porang (Amorphophallus oncophyllus Prain) atau seringkali disebut dengan iles-iles termasuk famili Araceae dan merupakan salah satu kekayaan hayati umbi-umbian Indonesia. Sebagai tanaman penghasil karbohidrat, lemak, protein, mineral, vitamin, dan serat pangan, tanaman porang sudah lama dimanfaatkan sebagai bahan pangan dan diekspor sebagai bahan baku industri. Meskipun demikian tanaman tersebut belum secara luas dibudidayakan. Tanah merupakan campuran dari beberapa komponen seperti mineral, senyawa organic, senyawa anorganik dan air. Tanah menyediakan air, udara dan nutrisi yang dibutuhkan makhluk hidup seperti organisme tanah dan tumbuhan. Dalam bidang pertanian tanah diartikan lebih khusus yaitu sebagai media tumbuhnya tanaman darat seperti pada budidaya porang.[1]

Porang (Amorphophallus oncophyllus Prain) sebagai tanaman penghasil, karbohidrat, lemak, protein, mineral, vitamin, dan serat pangan, tanaman porang sudah lama dimanfaatkan sebagai bahan pangan dan diekspor. Manfaat porang dapat dimanfaatkan pada berbagai industri pangan, kimia, dan farmasi.[1]

Keberhasilan dan kegagalan dalam budidaya porang ditentukan oleh kualitas tanah dan manajemen penggunaannya. Ketersediaan air pada masa pertumbuhan harus diperhatikan, jika kekurangan air daun porang akan kering dan akhirnya mati.[2] Dengan terpenuhinya kebutuhan air pada tanaman, maka tanaman dapat tumbuh dan berkembang biak dengan baik.[3]

Penelitian ini menerapkan alat monitoring suhu dan kelembaban tanah otomatis pada tanaman porang menggunakan sensor suhu dan kelembaban tanah berbasis Arduino agar dapat membantu meningkatkan hasil panen tanaman menjadi lebih baik. Mengingat betapa pentingnya mengontrol suhu dan kelembaban tanah bagi budidaya tanaman porang.

Berdasarkan latar belakang diatas, maka peneliti tertarik untuk mengangkat judul "Monitoring Suhu dan Kelembaban Tanah pada Budidaya Hidroponik Berbasis Arduino" sehingga Informasi perubahan suhu dan kelembaban tanah dapat termonitor secara 
otomatis ke LCD sehingga pengguna akan dapat memonitor tanaman porang tumbuh dengan baik dan agar memperoleh hasil panen yang optimal.

\section{Metode Penelitian}

Penelitian alat monitoring suhu dan kelembaban tanah pada budidaya porang menggunakan pemrograman arduino sangat penting dilakukan untuk mengeksekusi perintah yang dikehendaki pada rangkaian Arduino.[4] Saat hardware dimasukkan tegangan dalam hal ini catu daya, mikrokontroler akan memulai proses inisialisasi input maupun output serta variabel yang dibutuhkan. Data yang masuk ke dalam Arduino selanjutnya diolah. Bentuk flowchart dapat dilihat pada Gambar 1:

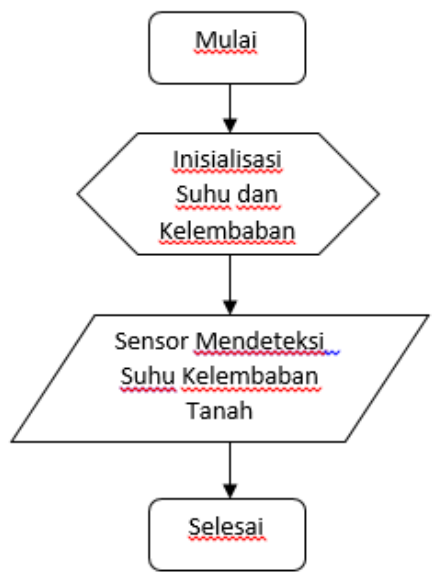

Gambar 1. Ilustrasi Cara Kerja Sistem Dalam rencana penelitian ini menggunakan metode SDLC (System Development Life Cycle)[5] dengan tahapan sebagai berikut, dapat dilihat pada gambar 2 :

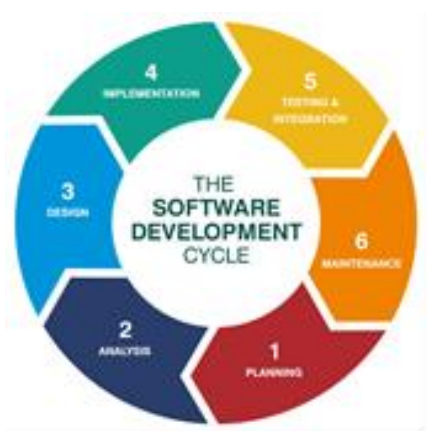

Gambar 2. Model Waterfall SDLC

\section{A. Planning (Perencanaan)}

Rencana yang dilakukan adalah mengumpulkan data dan mengamati pemilik tanaman porang dalam melakukan budidaya tanaman porang.

\section{B. Analysis (analisis)}

Melakukan analisis permasalahan yang timbul akibat pengelolaan tanaman porang kurang tepat yang menimbulkan tanaman porang tumbuh kurang baik. Dengan mengumpulkan data-data yang diperlukan sebagai bahan kajian maka diperlukan sebuah alat yang dapat memonitoring tanaman porang secara otomatis menggunakan sensor suhu dan kelembaban tanah sehingga memudahkan pemilik tanaman porang, agar memperoleh hasil panen yang optimal.

\section{Design (Desain)}

Tahapan perancangan setelah analisis dilakukan. Alat monitoring pada tanaman porang ini menggunakan sensor suhu kelembaban tanah sebagai input untuk membaca suhu dan tingkat kelembaban tanah melalui mikrokontroler NodeMCU ESP8266 yang kemudian akan mengirimkan datanya akan ditampilkan pada LCD.

\section{Implementation (Implementasi)}

Setelah dilakukan pengujian maka alat tersebut akan diimplementasikan kepada pemilik tanaman porang.

\section{E. Testing (Uji Coba)}

Setelah tahapan implementasi selesai dikerjakan, tahap selanjutnya adalah dengan melakukan pengujian hasil implementasi, yaitu dengan melakukan pengujian terhadap alat tersebut pada budidaya porang.

\section{F. Maintenance (Pemeliharaan)}

Tahapan terakhir dalam sistem ini adalah melakukan pemeliharaan, diantaranya yaitu dengan memperbaiki desain dan error program dan menjaga sistem dari kemungkinan masalah di masa yang akan datang.

Pembuatan alat Monitoring Suhu dan Kelembaban Tanah Pada Budidaya Porang ini terdiri dari perancangan software dan perancangan hardware. Perancangan software ini menggunakan software Arduino IDE yang dapat dijalankan pada sistem operasi berbasis Mikrokontroler.

Parameter yang diukur adalah sensor suhu dan sensor kelembaban tanah, kemudian akan menampilkan informasi LED dan informasi menampilkan sensor suhu dan sensor kelembaban tanah melalui LCD.

Perancangan perangkat keras terdiri dari sistem kontrol yaitu Arduino yang 
bertugas sebagai pengendali sensor serta pengolahan data.[6]

Perancangan melakukan sistem dipresentasikan dalam bentuk blok diagram yang akan membantu dalam membuat perancangan alat "Monitoring Suhu dan Kelembaban Tanah Pada budidaya Porang Berbasis Arduino". Adapun penggunaan Arduino sebagai pengolah data, sensor suhu dan kelembaban tanah. Penelitian ini bekerja menggunakan Mikrokontroler Arduino dengan menggunakan catu daya yang dapat mengukur suhu dan kelembaban tanah yang akan ditampilkan outputnya melalui LCD. Blok diagram alat monitoring suhu dan kelembaban tanah pada budidaya porang berbasis arduino dapat dilihat pada Gambar 3:

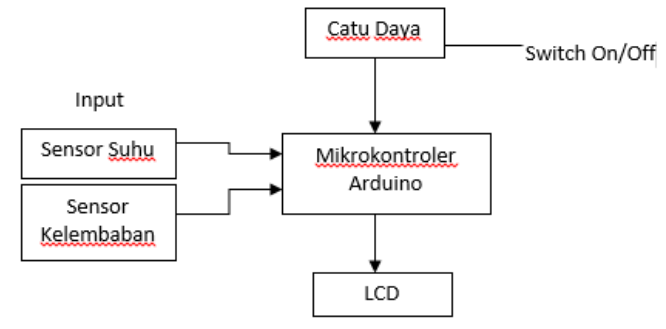

Gambar 3, Alat monitoring suhu dan kelembaban tanah pada budidaya porang.

\section{Skema Elektronik}

Perakitan perangkat keras merupakan proses dalam menghubungkan semua perangkat sehingga dapat membaca nilai sensor sampai memicu kinerja perangkat output Gambar 4, di bawah ini menunjukan rangkaian skematik dari sistem yang akan dibuat dapat dilihat pada Gambar 4:

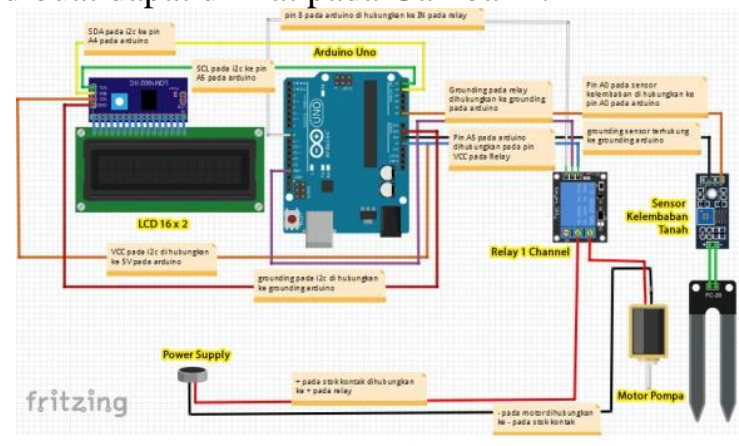

Gambar 4. Rangkaian Skematik keseluruhan Sistem

Persiapan alat-alat yang akan digunakan dalam pembuatan alat monitoring suhu dan kelembaban tanah dalam budidaya porang sebagai berikut :
1) Sensor suhu

Sensor suhu untuk membaca suhu air.

2) Sensor Kelembaban tanah/ Soil Moisture Sensor. Mengukur kelembaban tanah.

3) Mikrokontroler Arduino

Perancangan perangkat keras terdiri dari sistem kontrol yaitu Arduino yang bertugas sebagai pengendali sensor serta melakukan pengolahan data.

4) Adapter $12 \mathrm{v}$

5) LCD $18 \times 2$

Menampilkan Output/ keluaran.

\section{Hasil Dan Pembahasan}

A. Proses Perakitan Alat

Proses Perakitan alat monitoring suhu dan kelembaban tanah pada budidaya porang untuk memenuhi pengendalian objek dapat dilihat pada Gambar 5:

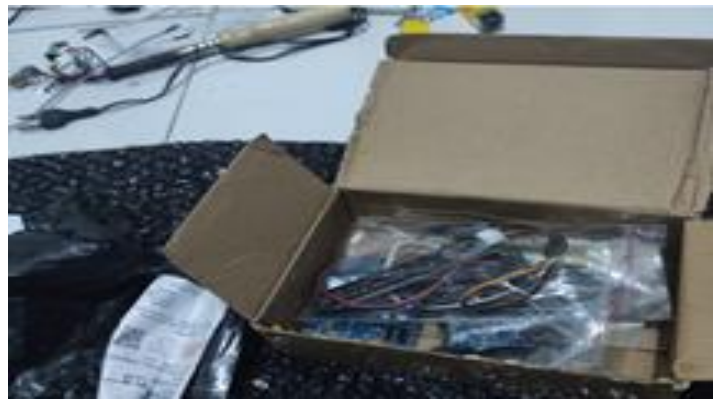

Gambar 5. Proses Perakitan Alat Monitoring Suhu dan Kelembaban tanah Pada Budidaya

\section{Porang}

\section{B. Instalasi perangkat alat monitoring} suhu dan kelembaban

Instalasi perangkat keras merupakan suatu proses instalasi alat ataupun perakitan alat yang digunakan dalam membangun Alat Monitoring Suhu dan Kelembaban Tanah Pada Budidaya Porang. Adapun Instalasi perangkat alat monitoring suhu dan kelembaban tanah pada budidaya porang dapat dilihat pada gambar 6:

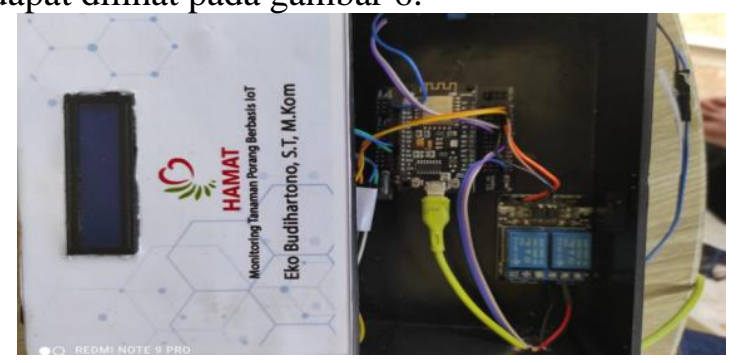

Gambar 6. Instalasi Perangkat Alat Monitoring Suhu dan Kelembaban Tanah Pada Budidaya Porang. 


\section{Tampilan Alat monitoring Suhu dan Kelembaban}

Tampilan digital sebagai pengendali utama dalam pengiriman teks pada LCD display, dimana teks yang dikirim akan ditampilkan pada Modul LCD. Sebelum pengiriman pastikan port sudah terdeteksi. Adapun hasil dari perakitan alat monitoring suhu dan kelembaban tanah pada budidaya porang, perangkat keras yang digunakan untuk memenuhi pengendalian objek dapat dilihat pada gambar 7 :

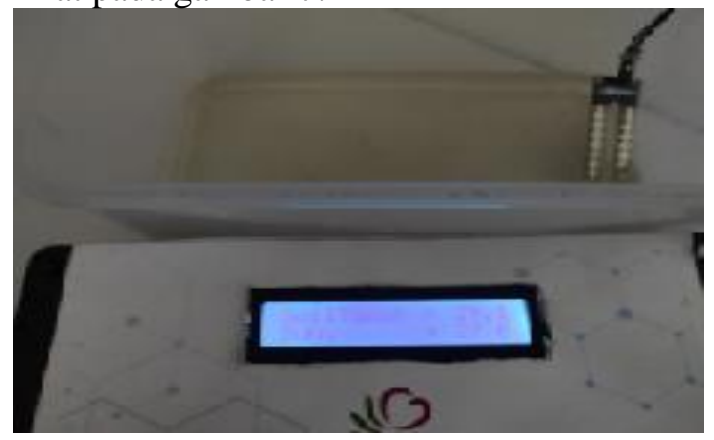

Gambar 7. Tampilan LCD Alat Monitoring Suhu dan Kelembaban Tanah Pada Budidaya Porang

\section{Pengujian Alat}

Untuk menemukan apakah perangkat lunak sudah berjalan sesuai dengan semestinya, tidak memiliki masalah error dan sesuai apa yang diharapkan. Pengujian menggunakan Metode BlackBox. Metode ini digunakan untuk mengetahui apakah perangkat lunak berfungsi dengan baik, perancangan data uji yang didasarkan pada spesifikasi perangkat lunak yang dibuat dapat dilihat pada tabel 1 :

Tabel 1. Pengujian Alat

\begin{tabular}{|c|c|c|c|c|}
\hline $\begin{array}{l}\mathbf{N} \\
\mathbf{o .}\end{array}$ & $\begin{array}{c}\text { Input } \\
\text { Pengujian }\end{array}$ & $\begin{array}{c}\text { Fung } \\
\text { si } \\
\text { Senso } \\
r \\
\end{array}$ & $\begin{array}{c}\text { Hasil } \\
\text { Yang } \\
\text { Diharapk } \\
\text { an } \\
\end{array}$ & $\begin{array}{c}\text { Hasil } \\
\text { Uji }\end{array}$ \\
\hline 1 & $\begin{array}{l}\text { Melakukan } \\
\text { pengujian } \\
\text { LCD }\end{array}$ & Aktif & $\begin{array}{l}\text { LCD aktif } \\
\text { terbaca } \\
\text { tulisan dan } \\
\text { huruf }\end{array}$ & $\begin{array}{l}\text { Mem } \\
\text { enuhi } \\
\text { /Akur } \\
\text { at }\end{array}$ \\
\hline 2 & $\begin{array}{l}\text { Melakukan } \\
\text { pengujian } \\
\text { suhu }\end{array}$ & Aktif & $\begin{array}{l}\text { Diharapka } \\
\mathrm{n} \quad \text { sensor } \\
\text { mendeteksi } \\
\text { suhu }\end{array}$ & $\begin{array}{l}\text { Mem } \\
\text { enuhi } \\
\text { /Akur } \\
\text { at }\end{array}$ \\
\hline 3 & $\begin{array}{l}\text { Melakukan } \\
\text { pengujian } \\
\text { Kelembaba } \\
\text { n tanah }\end{array}$ & Aktif & $\begin{array}{l}\text { Diharapka } \\
\mathrm{n} \quad \text { sensor } \\
\text { mendeteksi } \\
\text { kelembaba } \\
\mathrm{n} \text { tanah }\end{array}$ & $\begin{array}{l}\text { Mem } \\
\text { enuhi } \\
\text { /Akur } \\
\text { at }\end{array}$ \\
\hline & $\mathrm{T}$ & 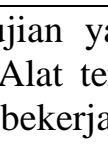 & & \\
\hline
\end{tabular}

keakuratan 99\%, mudah digunakan dan lebih efisien karena alat ini hanya membutuhkan catu daya untuk menampilkan di layar LCD dan mempermudah proses pengukuran suhu dan kelembaban tanah (Soil Moisture Sensor) sehingga diharapkan dapat membantu masyarakat dalam budidaya porang supaya hasil yang didapat lebih baik.

\section{Kesimpulan dan Saran}

A. Kesimpulan

Berdasarkan hasil penelitian yang telah dijelaskan sebelumnya, maka dapat diambil kesimpulan sebagai berikut:

1) Pembuatan Alat Monitoring Suhu dan Kelembaban Pada Budidaya Porang dapat mempermudah proses pengukuran suhu dan kelembaban tanah bekerja secara otomatis dengan keakuratan 99\% dan alat ini hanya membutuhkan catu daya.

2) Penelitian ini sangat berguna bagi masyarakat dalam budidaya porang di dalam memonitoring suhu dan kelembaban tanah sehingga pertumbuhan dan hasil yang didapatkan lebih maksimal dalam budidaya porang sehingga dapat meningkatkan taraf hidup masyarakat.

B. Saran

Saran yang dapat disampaikan berdasarkan penelitian yang telah dilaksanakan adalah sebagai berikut :

1) Perlu ditambahkan komponen/parameter yang lain agar lebih efektif dan efisien dalam budidaya porang. Perlu dibuat penyiraman otomatis berdasarkan kelembaban tanah.

2) Agar lebih efektif dan efisien dalam memonitoring kualitas air diharapkan bisa ditambahkan alat nodeMCU sebagai "Monitoring kelembaban, suhu, intensitas cahaya pada tanaman anggrek,"

3) penyimpanan data sensor ke website sehingga bisa di di monitoring melalui alat smartphone/ handphone. 


\section{Daftar Pustaka}

[1] N. Saleh, S. A. Rahayuningsih, B. S. Radjit, E. Ginting, D. Harnowo, and I. M. J. Mejaya, Tanaman Porang. 2015.

[2] R. A. Najikh, M. H. H. Ichsan, and W. Kurniawan, J. Pengemb. Teknol. Inf. dan Ilmu Komput. Univ. Brawijaya, vol. 2, no. 11, pp. 4607-4612, 2018.

[3] J. Desember and K. Tanah, "Rancang Bangun Alat Ukur Suhu Tanah, Kelembaban Tanah, dan Resistansi," $J$. Tek. Elektro, vol. 9, no. 2, pp. 80-86,
2017, doi: 10.15294/jte.v9i2.11087.

[4] E. Budihartono, Y. F. Sabanise, and Arif Rakhman, "Monitoring Kualitas Air pada Budidaya Hidroganik Berbasis Arduino," smart comp, vol. 10, no. 2, pp. 2-5, 2021.

[5] W. Dari, "Penerapan Metode System Development Life Cycle Pada Pembuatan Sistem Informasi Penjualan Produk Batik Kurowo Jakarta," vol. 3, no. 2, pp. 222-228, 2015.

[6] F. Djuandi, "Pengenalan arduino," pp. $1-1$. 